\title{
Grain Size Analysis of Surface Fluvial Sediments in Rivers in Kelantan, Malaysia
}

(Analisis Saiz Butiran Sedimen Permukaan Sungai di Kelantan, Malaysia)

\author{
Wan Hanna Melini Wan MohtaR*, Siti Aminah Bassa \& MoJTABa Porhemmat
}

\begin{abstract}
Grain size spectrum and textural parameters for the fluvial sediment bed in seven tropical rivers of Kelantan, Malaysia are presented in this article. The samples were collected from six tributaries to the main Sungai Kelantan spanning approximately $248 \mathrm{~km}$ stretch of water streams. Sand or gravel dominated river was identified for each river using the sediment composition analysis. Textural pattern shows complicated profiles of mean size and no consistent decreasing grain size and gradation parameter were observed towards the downstream flow. Most of the samples fall under the category of either very poorly sorted or poorly sorted and has very platykurtic kurtosis distributions. CM diagram ( $C=$ one percentile in microns and $M=$ median grain size in microns) suggested that the deposition of fine-grained sediment for samples with median grain size $d_{50}<1 \mathrm{~mm}$ are either by rolling, rolling and saltation or saltation and suspension.
\end{abstract}

Keywords: CM diagram; fluvial sediment; grain size; sediment composition analysis; tropical rivers

\section{ABSTRAK}

Saiz butiran spektrum dan parameter tekstur untuk sedimen di dasar tujuh sungai tropika Kelantan, Malaysia dibincangkan dalam kertas ini. Sampel telah diambil daripada enam anak sungai utama kepada Sungai Kelantan yang merangkumi kira-kira 248 km sepanjang sungai. Pasir atau batu kelikir di sungai yang mendominasi telah dikenal pasti untuk setiap sungai menggunakan analisis komposisi sedimen. Corak tekstur menunjukkan profil rumit bagi saiz min dan tiada penurunan saiz butiran dan penggredan parameter secara tekal diperhatikan mengikut arah menuju hiliran. Kebanyakan sampel berada dalam kategori sama iaitu amat tidak terisih atau kurang terisih dan mempunyai taburan kurtosis sangat platikurtik. Gambarajah $\mathrm{CM}(C=$ satu peratus dalam mikron dan $M=$ saiz butiran median dalam mikron) menunjukkan bahawa pemendapan sedimen halus untuk sampel dengan median saiz butiran $d_{50}<1 \mathrm{~mm}$ adalah sama ada dengan olengan, olengan dan loncatan atau loncatan dan ampaian.

Kata kunci: Analisis komposisi sedimen; gambarajah CM; saiz butiran; sedimen sungai; sungai tropika

\section{INTRODUCTION}

Soil erosion from the river basins not only resulted in 15 to $2010^{9}$ billion tons of sediment flux to the oceans in the world but also caused a significant loss of fertile agricultural land (Milliman \& Ren 1995). The soil is being redistributed and causing problems for river management and control. The redistribution of soil may result in the changes of particle size distribution of fluvial sediment, where the grain size is the most fundamental property to determine the entrainment, bed load transport and prediction of suspended sediment and deposition (McLaren $\&$ Bowles 1985).

Grain size studies of fluvial sediments provide substantial informations on the intrinsic properties or sediments. It provides the fundamental physical properties in controlling channel morphology and hydraulics of the stream (Di Stefano \& Ferro 2002; Surian 2002). Systematic granulometric studies of both fluvial and marine sediment able to give an overview of the depositional conditions and transport histories (Blott 2001; Mychielska-Dowgiallo 2011).
The tropical rivers often used as logging transportation, water resources, irrigation and act as focal points of the establishment of town and cities. Spatial characteristics of land use including plantations and residential area may have an impact on the fluvial grain size distributions. The downstream changes in flow resistance and sediment transportation are closely related to rate of change in sediment size (Surian 2002). Fully dispersed size distribution (ultimate grain size distribution) is important in certain soil chemical and physical properties but others relevant process such as soil erosion and sediment transport by overland flow, are dependent on the size distribution on soil aggregates (effective grain size distribution) (Di Stefano 2002; Foster 1985). The enrichment of sediments cause by the erosion and transport of silt and clay particles were the most effective scavengers of chemical pollutants (Rhoton et al. 2011). Both fine and coarse size fractions affect the downstream fining process. Within the downstream direction, sorting progressively was improved and the larger percentiles may caused the higher rates of fining occurred (Gomez et al. 2001). 
The properties of sediment varies according to climate, whether temperate or arid areas (Thomas 2003). This study attempts to investigate the longitudinal granulometric characteristics of grain size in tropical rivers in the state of Kelantan, Malaysia. The country experiences a humid tropical climate where the sediment type spans from fine to coarse grained sediments and different type of sediment such as sand, quartz, gravel, clay and silt (Kiat 2011). Six rivers as tributaries to a main river (Sungai Kelantan) were selected to study the grain size variation and focused to investigate the general pattern along the tributaries. Methods of sampling, sieving process and statistical analysis are discussed in detail in the following subsections.

\section{MATERIALS AND METHODS}

\section{STUDY AREA}

Sediment samples were collected from the rivers in the state of Kelantan situated in the north east of Peninsular Malaysia (Figure 1). Eight rivers were identified and each river has differences in setting and scale. Table 1 shows the specification of each river including the length, nearest point to the shoreline, catchment area and the river pattern. The main river, Sungai Kelantan runs through most of the main cities of Kuala Krai, Tanah Merah, Pasir Mas and the capital Kota Bharu, where the catchment area spanned about $12000 \mathrm{~km}^{2}$ (Ahmad et al. 2009). Approximately, 400 $\mathrm{km}^{2}$ of an alluvial delta and coastal plain stretching o the coast of Kelantan facing the south China Sea (Samsudin et al. 2007). Sungai Kelantan receives rainfall from 0 and up to $17.5 \mathrm{~cm}$ in dry and wet months, due to the variation of the local monsoon climate and produces total average run off approximately $500 \mathrm{~m}^{3} / \mathrm{s}$ (Ahmad et al. 2009). The river depth was measured up to $18 \mathrm{~m}$ in localised area. Mount Korbu is the highest point for Sungai Kelantan approximately 2, $183 \mathrm{~m}$ from the sea level and this river is full with geological features of shale, mudstone and limestone (Ibbit et al. 2002). The catchment area of Sungai Kelantan has several active activities including plantation and developed urban areas. From Kuala Krai to Tanah Merah, land use are mostly for the oil palm, coconut and rubber plantations. The river passes through Pasir Mas,

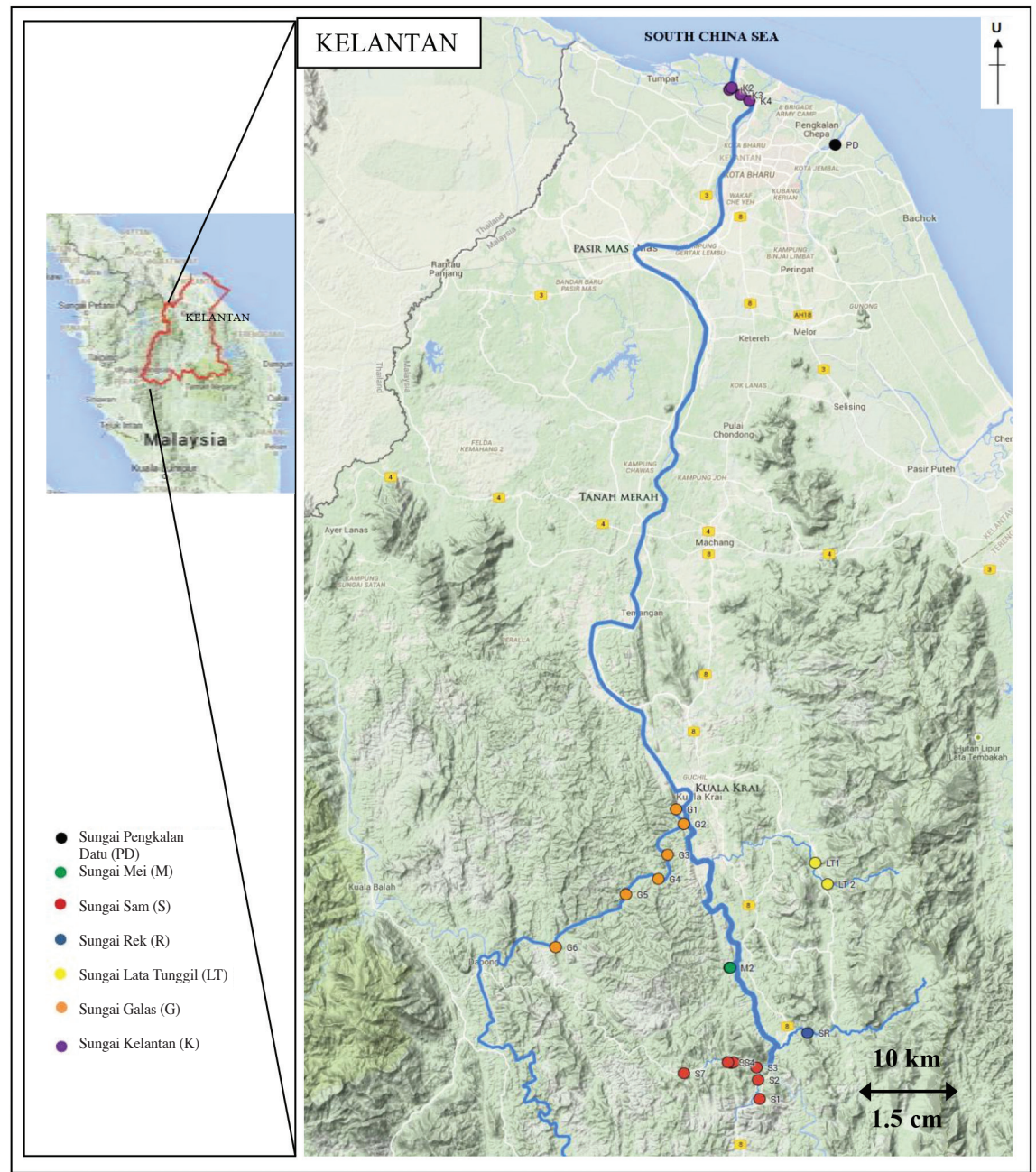

FIGURE 1. Sampling points within downstream area (K1, G1, S3, M1, LT1, PD and $\mathrm{R}$ were the most downstream point for each river) 
which is a big town and quite a large scale of paddy field plantation. The downstream of Sungai Kelantan, is the urbanised, densely populated capital Kota Bharu. The samples for Sungai Kelantan were taken at the lower course, about $3 \mathrm{~km}$ from the shoreline. Sungai Kelantan receives its waters from two tributaries of Sungai Galas and Sungai Lebir and the point of confluences is about 10 km away from the Kuala Krai town.

Sungai Kelantan is widely used for domestic uses, transportation, agriculture, plantation, small scale fishing industries. Sand mining activities were notably caused the increasing of water turbidity since early 1990s due to hogh suspended solids and siltation (Ahmad et al. 2009; Ambak \& Zakaria 2010). Along the Sungai Kelantan, approximately 128 sand mining activities were operating due to high demand of sand for industry and construction (Ambak et al. 2010). Sungai Galas stretched about 179.5 $\mathrm{km}$ starting from the borderline of Kelantan-Pahang states. The river flows through the remote areas with low density populations. Six samples, spatially distributed were collected from those river, where the most upstream accessible (by boat) is the G6 point (Figure 2).

Sungai Lebir has a length of $34.2 \mathrm{~km}$, with thirty rivers as its tributaries. In this study, samples from four tributaries were collected i.e Sungai Sam, Sungai Mei, Sungai Rek and Sungai Lata Tunggil. Figure 2 shows a close up image on the samples collection points and the tributaries of Sungai Lebir. Sungai Sam, the most upstream tributary (in this study) comprises of two-stem rivers with and kilometers for the left and right rivers, respectively. Six samples (i.e. S1 and S6) were taken from Sungai Sam, where samples $S 1$ to $S 3$ were obtained from the left stem of the river and samples S4 to S6 were taken from the right stem. Both rivers met at point $\mathrm{S} 3$, where here a sample too was collected.
Bed materials were taken at one sampling point at Sungai Rek and Sungai Mei, labelled in Figure 2 as SR and M2, respectively. Both rivers are surrounded with virgin forest and have minimum populations. Sediment samples from Sungai Lata Tungggil, the most downstream tributary to Sungai Lebir were taken about $18.8 \mathrm{~km}$ from the confluence point. This river is suitable and famous for recreational activities. The sample from Sungai Pengkalan Datu, another river flowing to the South China Sea was also collected, specifically to compare with the bed materials obtained from Sungai Kelantan. The river flows through the urban area, mostly commercial and residential buildings.

\section{SEDIMENT SAMPLING}

Sampling period was conducted during a dry season in March 2014. This study was designed to capture the grain size distribution of the bed materials, as such all samples were consistently obtained from the river bed, close to the active channels. The samples of sediment were taken at each sampling point using a stainless steel grab sampler and were immediately sealed in an airtight container. Prior to analysis, all samples were allowed to settle, dried and placed in plastic boxes for storage. The sampler has maximum permissible volume of $0.002 \mathrm{~m}^{3}$ for each sampling. The grab sampling allows the collection of sediment including sediment transported solely along the bed and the suspended material which is temporarily settled on the bed and/or trapped interstitially amongst the bedload particles (Hajek 2010).

There were 22 samples obtained from all sampling points; four samples from Sungai Kelantan, six samples from Sungai Galas and Sungai Sam, two samples from Sungai Mei and Sungai Lata Tunggil and one sample from Sungai Rek and Sungai Pengkalan Datu, respectively. The

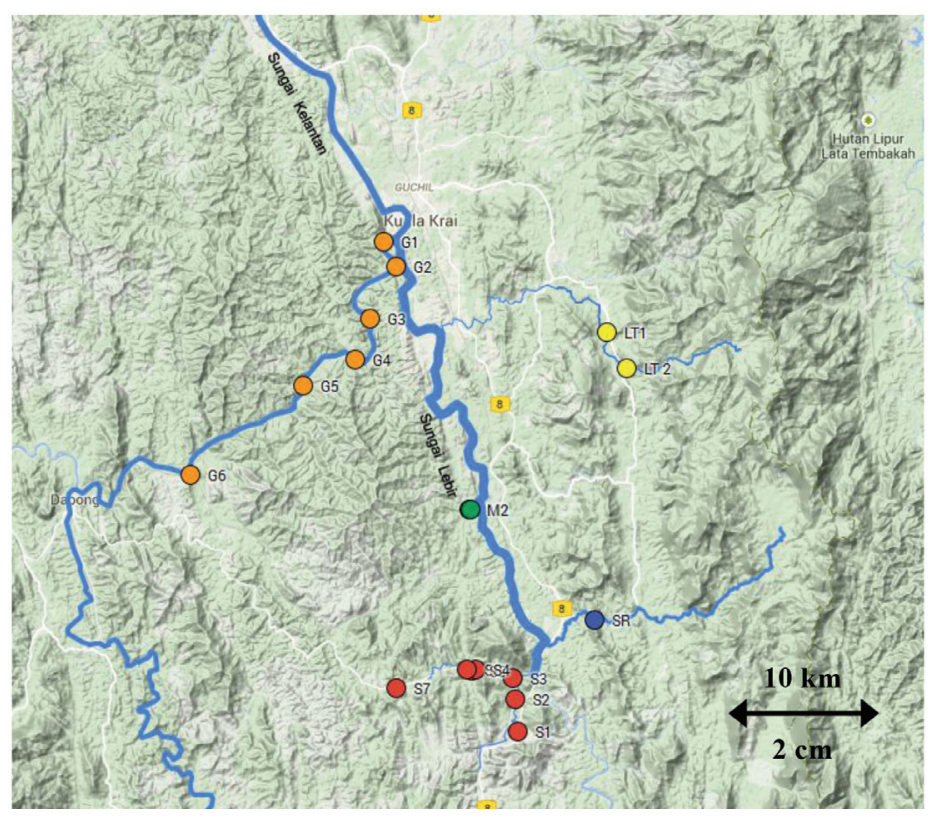

FIGURE 2. Sampling collection points for Sungai Galas and tributaries of Sungai Lebir 
sediment taken were analysed to study the variations of the grain sizes $\left(d_{50}\right)$, mean $(M)$, skewness $\left(S_{k}\right)$ and kurtosis $\left(K_{G}\right)$ classification, coefficient of uniformity and percentage of soil within the downstream river by using sieving analysis method. These two methods were used to see the variation of the grain size distribution smaller than $0.075 \mathrm{~mm}$ and up to $4.75 \mathrm{~mm}$ for each of the sampling site.

\section{SEDIMENT GRAIN SIZE}

The samples were dried in the oven at $105^{\circ} \mathrm{C}$ for $12 \mathrm{~h}$ prior physical sieving. The samples were continued with sieve analysis, a procedure commonly used in engineering to assess the particle size distribution of a granular material includes of sand (Sonaye \& Baxi 2012). Sieve series of $4.75,2.36,1.18,0.6,0.3,0.15$ and $0.075 \mathrm{~mm}$ in sizes were chosen in this sieve analysis. The nest of sieves was put through on sieve shakers for $10 \mathrm{~min}$. The percentages of the sample retained and passed through the sieves were calculated using the following formulas:

$\%$ retained: $\frac{w_{s}}{w_{f}} \times 100$,

Mass loss $(\%): \frac{w_{f}}{w_{t}} \times 100$,

(is accepted if less than 2\%)

The symbol $w_{s}$ denotes weight retained in the siever, whereas $w_{f}$ and $w_{t}$ are the final weight after sieving and weight before sieving. In order to have a full spectrum of the grain size distribution, particles below than $75 \mu \mathrm{m}$ (obtained from the sieve analysis) was measured using the Mastersizer 2000 (MU), a laser particle-size analyzer with the minimum detected size is $2 \mu \mathrm{m}$. The speed of the pump (2500 rpm) was selected so as to obtain maximum homogenization of the suspension in a beaker while eliminating the air bubbles from the suspension. These methods ensure to provide wide range characterisation of fine and coarse tails of the samples. Sediment type of clay, silt, fine sand and coarse sand is identified as sediment with sizes of $<0.002,0.002-0.5$ and $>2 \mathrm{~mm}$, respectively.
The statistical measurements includes of central tendency (median, mode and mean); a measure of degree of scatter of sorting, kurtosis, the degree of peakedness and skewness. The logarithmic original formula for Folk and Ward (1957) as described in Table 1. Sorting or standard deviation measures $\sigma_{1}$ the sorting of sediment and indicates the fluctuations in the kinetic energy or velocity conditions of the depositing agent (Sahu 1964).

\section{RESULTS AND DISCUSSION}

The bed material size was analysed in terms of the median grain size $d_{50}, d_{84}$, gradation parameter $\sigma_{g}$. Sediment taken from Sungai Galas, Sungai Lata Tunggil, Sungai Rek and Sungai Pengkalan Datu was found to be uniformly nearspherical shape, whilst the samples from Sungai Kelantan, Sungai Sam and Sungai Mei are near-spherical sediment with fractions of sub-angular particles.

\section{TEXTURAL ATTRIBUTES OF SEDIMENT}

The statistical analysis reported the cumulative probability curve provides the mean, standard deviation, skewness and kurtosis for each sediment sample (as described in Table 2). The fluvial sediments from the tropical rivers in Kelantan show a wide range of textural facies including fine, medium, coarse sands and gravels. Interestingly, there is no consistent pattern of downstream locations were enriched with the fine sand. Overall, most of the sediments has relatively high sorting values and categorised as very poorly sorted, with couples of samples fall under the category of poorly sorted. Kurtosis analysis show that all samples (except SK1) are better sorted at the tail than the central portions, hence the very platykurtic curves. The nature of measured kurtosis values indicates that the sands are of matured and is believed due to aggregation of sediment particle size by compaction and variation in the sorting values (Ramanathan 2010).

The samples obtained from Sungai Kelantan show a variation in the median grain size between 0.54 and 1.05 $\mathrm{mm}$ and are categorised as medium sand. The sediment is very poorly sorted, with standard deviation as high as 3.02. The rather large variation of $d_{50}$ is believed due to

TABLE 1. Statistical formulate used in the calculation of grain size parameters using the logarithmic Folk and Ward (1957) graphical measures

\begin{tabular}{|c|c|c|c|c|c|}
\hline Mean & \multicolumn{2}{|c|}{ Standard deviation } & \multicolumn{2}{|r|}{ Skewness } & Kurtosis \\
\hline$\left(M_{z}\right)=$ & \multicolumn{2}{|c|}{$\left(\sigma_{1}\right)=$} & & $\begin{array}{c}\left(S k_{1}\right)= \\
+\end{array}$ & $\left(\mathrm{K}_{G}\right)=$ \\
\hline \multicolumn{2}{|l|}{ Sorting $\left(\sigma_{1}\right)$} & \multicolumn{2}{|c|}{ Skewness $\left(S k_{1}\right)$} & \multicolumn{2}{|c|}{ Kurtosis $\left(\mathrm{K}_{G}\right)$} \\
\hline Very well sorted & $<0.35$ & Very fine skewed & ${ }^{+} 0.3$ to ${ }^{+} 1.0$ & Very platykurtic & $<0.67$ \\
\hline Well sorted & $0.35-0.5$ & Fine skewed & ${ }^{+} 0.1$ to ${ }^{+} 0.3$ & Platykurtic & $0.67-0.9$ \\
\hline Moderately well sorted & $0.7-1.00$ & Symmetrical & ${ }^{+} 0.1$ to -0.1 & Mesokurtic & $0.9-1.11$ \\
\hline Poorly sorted & $1.00-2.00$ & Coarse skewed & -0.1 to 0.3 & Leptokurtic & $1.11-1.5$ \\
\hline Very poorly sorted & $2.00-4.00$ & Very coarse skewed & 0.3 to -1.0 & Very leptokurtuic & $1.5-3.00$ \\
\hline Extremely poorly sorted & $>4.00$ & & & Extremely leptokurtic & $>3.0$ \\
\hline
\end{tabular}


the low and high energy regions where the samples were collected (due to the wide length of the river). Bed materials obtained from Sungai Galas on the other hand has smaller grain sizes, varying from 0.2 to $0.98 \mathrm{~mm}$, falling into the categories between fine to medium sand. The median grain size obtained shows inconsistent decreasing grain size towards downstream hinting that the downstream fining processes is not visible. This is probably due to the lateral sediment input along the river bank.

Recall that Sungai Sam has two river stems, where the right stem (i.e. S1 to S3) shows a consistent decreasing trend of grain size from 1.72 to $0.98 \mathrm{~mm}$. On the other hand, the left stem river show inconsistent of downstream fining where the middle point has bigger size than the most upstream point $(1.5 \mathrm{~mm}$ compared to 1.8 $\mathrm{mm}$, respectively). Bed materials from Sungai Sam are medium sand, very poorly sorted and very platykurtic. The downstream tributary of Sungai Mei gives medium sand fluvial sediment with median grain size of 0.5 and
$0.98 \mathrm{~mm}$ from two collection points. The sorting values varies with one sample is very poorly sorted and another one is poorly sorted. The bed material sample taken from Sungai Rek on the other hand show a median grain size of $1.5 \mathrm{~mm}$, coarse sand and very poorly sorted.

Sungai Pengkalan Datu has $0.98 \mathrm{~mm}$ size of medium sand, very poorly sorted and is comparable to the sediments obtained at Sungai Kelantan for samples SK2 and SK4. This indicate that sediments entering coastal region along the Kota Bharu coastline is medium sand with approximately $1 \mathrm{~mm}$ in size. For the three rivers of Sungai Kelantan, Sungai Galas and Sungai Sam with more than two sampling points were available, the grain size distribution for each sample is plotted on a log$\log$ scale as shown in Figure 3. This is to investigate the spatial variations of grain size distributions in the samples. Overall, bed materials can be considered to have unimodal distribution, with noticeable fine-grained tail. Data shows consistent differences between grain size

TABLE 2. Statistical analysis of grain size in the rivers in Kelantan

\begin{tabular}{|c|c|c|c|c|c|c|c|c|}
\hline $\begin{array}{c}\text { Sample } \\
\text { No. }\end{array}$ & Mean & $\begin{array}{l}\text { Stan. } \\
\text { Dev. }\end{array}$ & $\begin{array}{l}\text { Skew } \\
(\mathrm{Sk} 1)\end{array}$ & $\begin{array}{c}\text { Kurtosis } \\
\left(\mathrm{K}_{G}\right)\end{array}$ & Mean & Standard deviation & Skewness & Kurtosis \\
\hline SK1 & 0.674 & 2.331 & 1.104 & 3.634 & Medium sand & Very poorly sorted & Very fine skewed & Extremely leptokurtic \\
\hline SK2 & 1.047 & 2.655 & 1.068 & 0.488 & Medium sand & Very poorly sorted & Very fine skewed & Very platykurtic \\
\hline SK3 & 0.535 & 3.021 & 1.258 & 0.282 & Medium sand & Very poorly sorted & Very fine skewed & Very platykurtic \\
\hline SK4 & 1.034 & 1.969 & 1.040 & 0.477 & Medium sand & Poorly sorted & Very fine skewed & Very platykurtic \\
\hline SG1 & 0.501 & 2.478 & 1.029 & 0.539 & Medium sand & Very poorly sorted & Very fine skewed & Very platykurtic \\
\hline SG2 & 0.274 & 1.375 & 0.793 & 0.359 & Fine sand & Poorly sorted & very fine skewed & Very platykurtic \\
\hline SG3 & 0.748 & 1.725 & 0.919 & 0.476 & Medium sand & Poorly sorted & very fine skewed & Very platykurtic \\
\hline SG4 & 0.981 & 2.278 & 1.135 & 0.469 & Medium sand & Very poorly sorted & very fine skewed & Very platykurtic \\
\hline SG5 & 0.204 & 2.411 & 0.687 & 0.628 & Fine sand & Very poorly sorted & very fine skewed & Very platykurtic \\
\hline SG6 & 0.578 & 2.855 & 1.637 & 0.176 & Medium sand & Very poorly sorted & very fine skewed & Very platykurtic \\
\hline $\mathrm{SS} 1$ & 0.981 & 2.276 & 1.134 & 0.407 & Medium sand & Very poorly sorted & Very fine skewed & Very platykurtic \\
\hline SS2 & 1.180 & 3.702 & 1.369 & 0.499 & Medium sand & Very poorly sorted & Very fine skewed & Very platykurtic \\
\hline SS3 & 1.718 & 2.721 & 1.425 & 0.550 & Medium sand & Very poorly sorted & Very fine skewed & Very platykurtic \\
\hline SS4 & 0.804 & 2.884 & 1.269 & 0.445 & Medium sand & Very poorly sorted & Very fine skewed & Very platykurtic \\
\hline SS5 & 1.797 & 3.043 & 1.623 & 0.581 & Medium sand & Very poorly sorted & Very fine skewed & Very platykurtic \\
\hline SS6 & 1.495 & 3.151 & 1.424 & 0.607 & Medium sand & Very poorly sorted & Very fine skewed & Very platykurtic \\
\hline SM1 & 0.469 & 1.776 & 0.929 & 0.468 & Medium sand & Poorly sorted & Very fine skewed & Very platykurtic \\
\hline SM2 & 0.986 & 2.589 & 0.966 & 0.564 & Medium sand & Very poorly sorted & Very fine skewed & Very platykurtic \\
\hline SR & 1.512 & 2.220 & 1.0767 & 0.599 & Medium sand & Very poorly sorted & Very fine skewed & Very platykurtic \\
\hline SLT1 & 2.550 & 1.670 & 1.1859 & 0.516 & Medium sand & Poorly sorted & Very fine skewed & Very platykurtic \\
\hline SLT2 & 1.765 & 2.265 & 1.2404 & 0.579 & Medium sand & Very poorly sorted & Very fine skewed & Very platykurtic \\
\hline SPD & 0.983 & 4.000 & 1.2878 & 0.447 & Medium sand & Very poorly sorted & Very fine skewed & Very platykurtic \\
\hline
\end{tabular}



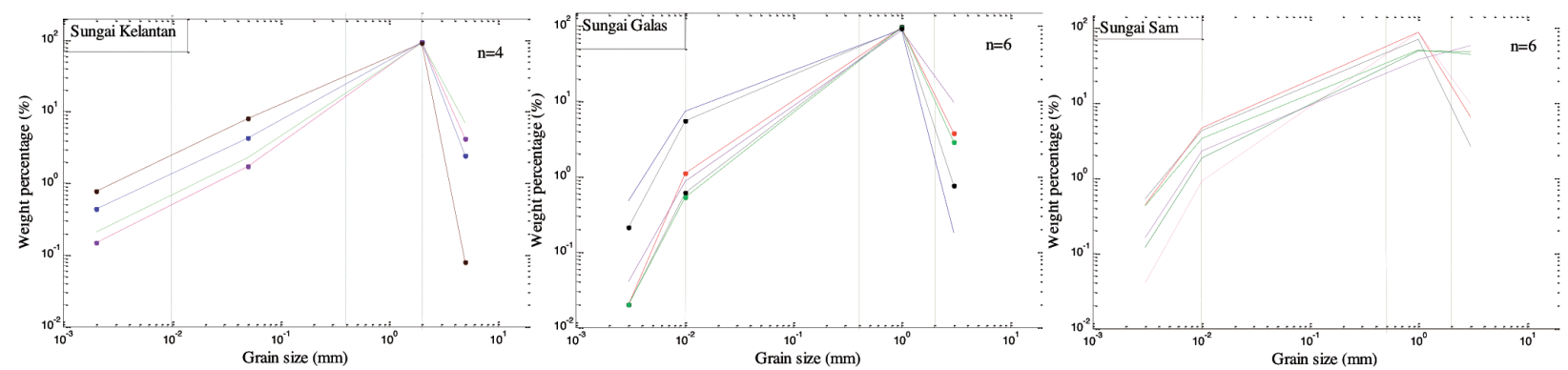

FIGURE 3. Grain size distribution of samples plotted on log-log scale for (a) Sungai Kelantan, (b) Sungai Galas and (c) Sungai Sam. Vertical light-gray lines on each plot represent the limit of grain size between, from left to right clay/silt, silt/sand and sand/gravel

distributions with in and between the rivers, in particular within the fine-grained tail for samples of Sungai Galas and Sungai Sam.

\section{MIXTURE DISTRIBUTION}

The mixture distribution i.e. soil composition of the samples obtained from each river was conducted. However, for a clear presentation, only selected samples will be discussed here. Table 3 shows percentage of clay, silt, sand and gravel fractions for samples and their corresponding soil classification according to the Unified Soil Classification System (USCS) and Unified Soil Department of Agriculture (USDA) guidelines.

The big rivers of Sungai Kelantan and Sungai Galas has median size grain $d_{50}$ about 0.72 and $0.53 \mathrm{~mm}$, respectively. The bed materials from both rivers show very minimal percentage of clay approximately below $1 \%$ and only below $4 \%$ of gravel. The result is rather interesting as it was expected that the downstream samples will have finer sizes compared to the upstream. Recall that the samples of Sungai Galas were taken about $103 \mathrm{~km}$ away whilst Sungai Kelantan is the nearest to the coastline almost $3 \mathrm{~km}$. For comparison, the median grain size $d_{50}$ for Sungai Pengkalan Datu is 1.21 $\mathrm{mm}$, about $50 \%$ bigger than the sediment found in Sungai
Kelantan. This is rather expected as Sungai Pengkalan Datu is shorter and the deposition of the gravel material is still occuring close to the shoreline.

The tributaries to Sungai Lebir show a varying median grain size where Sungai Lata Tunggil and Sungai Sam have $d_{50}>2 \mathrm{~mm}$, i.e 2.67 and $2.37 \mathrm{~mm}$, respectively. On the other hand, bed materials collected from Sungai Rek and Sungai Mei are coarse sand with $d_{50}$ of 1.61 and $0.95 \mathrm{~mm}$, respectively. Analysis showed that the tributaries contributing to Sungai Kelantan has (rather) fine bed materials with $d_{50}$ of $0.5 \mathrm{~mm}$ and Sungai Lebir with tributaries of large sediment sizes $(>1 \mathrm{~mm})$. The bed materials found at the downstream of Sungai Kelantan $d_{50}$ $=0.7 \mathrm{~mm}$ may be the results of responses from the lateral sources and anthropogenic interventions in the fluvial system. The plantations and urbanised area may have a significant contribution to the changes of grain size in the downstream, although this is yet to be asserted with confidence.

The natural factors such as tributaries, bedrock outcrops and terraces, injecting material with characteristics established independently of processes which operate longitudinally within the recipient channel (Rice \& Church 1998). Two rivers, Sungai Galas and Sungai Sam located within the virgin forest and few settlement of village

TABLE 3. The percentange of clay, silt, sand and gravel fractions for each sample

\begin{tabular}{|c|c|c|c|c|c|c|c|c|}
\hline \multirow[t]{4}{*}{ Sample } & \multirow[t]{4}{*}{$d_{50}(\mathrm{~mm})$} & \multirow[t]{4}{*}{$\sigma_{g}$} & \multicolumn{4}{|c|}{$\%$ soil } & \multirow[t]{4}{*}{ USCS } & \multirow[t]{4}{*}{ USDA } \\
\hline & & & Clay & Silt & Sand & Gravel & & \\
\hline & & & \multicolumn{4}{|c|}{$(\mathrm{mm})$} & & \\
\hline & & & $<0.002$ & $0.002-0.05$ & $0.05-2$ & $>2$ & & \\
\hline Sungai Kelantan & 0.72 & 2.33 & 0.44 & 4.36 & 92.80 & 2.40 & SP & Sand \\
\hline Sungai Galas & 0.53 & 2.48 & 0.02 & 1.10 & 95.07 & 3.80 & SP & Sand \\
\hline Sungai Sam & 2.37 & 2.72 & 0.12 & 1.87 & 49.48 & 48.53 & SW & Silt loam \\
\hline Sungai Mei & 0.95 & 2.58 & 0.03 & 0.91 & 79.78 & 19.28 & SP & Loamy sand \\
\hline Sungai Lata Tunggil & 2.67 & 1.67 & 0.01 & 0.12 & 41.97 & 57.9 & SP & Silt loam \\
\hline Sungai Pengkalan Datu & 1.21 & 4.00 & 0.39 & 7.80 & 69.21 & 22.6 & SW & Sandy loam \\
\hline Sungai Rek & 1.61 & 2.22 & 0.48 & 0.62 & 66.95 & 32.4 & SP & Sandy loam \\
\hline
\end{tabular}


people may no affected with the factors of urbanisation and chemicals. Besides, the sample taken of Sungai Sam were more to upstream of the river and caused the $d_{50}$ of the samples were higher than others except Sungai Pengkalan Datu. Both the median grain size $d_{50}$ recorded for Sungai Lata Tunggil and Sungai Rek were quite similar which were 1.64 and $1.61 \mathrm{~mm}$, respectively.

Classification of soil according the USDA guidelines give both sediments from Sungai Kelantan and Sungai Galas is sand, silt loam for Sungai Lata Tunggil and Sam, loamy sand for Sungai Mei and both Sungai Pengkalan Datu and Rek has sandy loam. Overall, the percentage of clay for all samples are negligible where all were measured below $1 \%$. Sungai Pengkalan Datu has the highest silt with $7.8 \%$ and Sungai Kelantan has the second high amount of silt with $4.36 \%$. Other samples showed an insignificant amount of silt in their bed materials.

Sand is notably dominated in Sungai Kelantan and Galas where 92.8 and $95.1 \%$, respectively of the bed materials fall under the classification of sand. The presence of gravel is rather minimal with only about $2.4-3.8 \%$. Sungai Mei also has significant fractions of sand with almost $80 \%$ and $19 \%$ of gravel. Bed materials from Sungai Pengkalan Datu and Sungai Rek have approximately $69.2 \%$ and $67.0 \%$ of sand, respectively. Even so, Sungai Pengkalan Datu has less gravel, about $10 \%$ less than Sungai Rek, as Pengkalan Datu has quite significant fraction of silt. The rivers with big median grain size (i.e. Sungai Sam and Sungai Lata Tunggil) were evidently shown with less fraction of sand and is more dominated by gravel. All collected river sediments showed a negatively skewed towards coarse sand distribution and has very small percentage of cohesive sediment with below than $1 \%$ of clay and $8 \%$ of silt. It can be concluded that the identified sand-dominated rivers are Sungai Kelantan, Sungai Galas, Sungai Mei, whilst the gravel-dominated rivers are Sungai Sam, Sungai Lata Tunggil and Sungai Pengkalan Datu.

All samples show no uniformly distributed sediment with every sample has gradation parameter more than 1.4. The highest value was found in the samples collected Sungai Pengkalan Datu (i.e. 4.0) and lowest value was obtained at Sungai Lata Tunggil (i.e. 1.7). Most of the samples, including the sand-dominated rivers (i.e. Sungai Kelantan and Sungai Galas) have non-uniformly distributed sediment ranging between 2.22 and 2.72.

A detailed box-plot representation of the grain size distribution for each river is shown in Figure 4. Note that the boxplot corresponds to the same data presented in Table 2. Data evidently show that samples from Sungai Galas has the lowest varying distribution where as Sungai Rek, Sungai Lata Tunggil and Sungai Pengkalan Datu have wider distribution.

\section{THE GRAIN SIZE PATTERN OF THE RIVERS IN KELANTAN}

The data obtained does not permit for a comprehensive downstream fining analysis. However, the set of data is worthy of some consideration to give an overview of

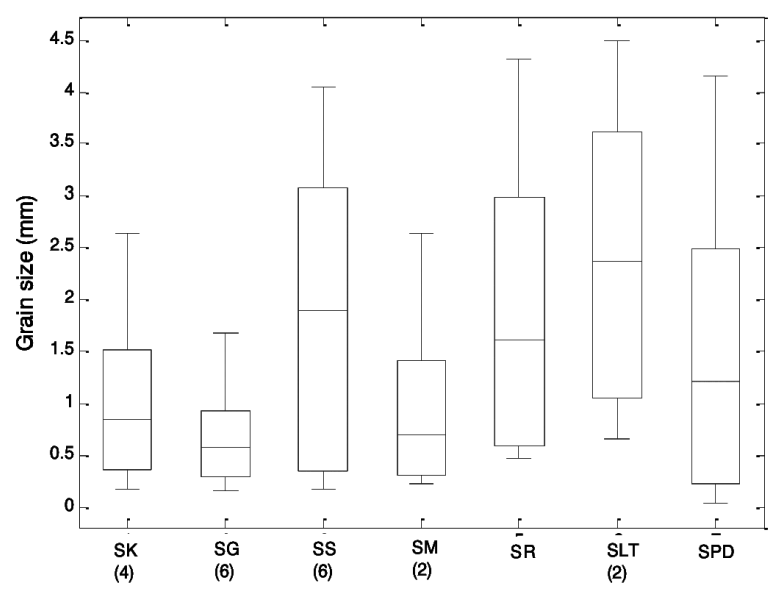

FIGURE 4. Boxplots of selected fluvial sediment samples obtained from each river. Boxes show the range from the first to third quartiles, with the median is indicated by a line. The dashed line and brackets show the range of observations

the grain size pattern along the Sungai Kelantan and its tributaries. The downstream variation in grain size was analysed in terms of $d_{50}$ and is plotted according to their distance from the shoreline.

Data in Figure 5 shows that the bed materials further away i.e. $>130 \mathrm{~km}$ from the shoreline has median grain size $d_{50}$ more than $1.5 \mathrm{~mm}$. Downstream grain size has a decreasing trend towards the shoreline, although the data at Sungai Pengkalan Datu shows a different trend. This is to be expected due to its short distance.

\section{PATTERNS}

The mode of tranports and depositional histories for the samples obtained were distinguished with the application of the C-M diagram (Mycielska-Dowgiallo 2011; Passega \& Byramjee 1969). Note that however, the diagram is only valid for fine-grained sediment with $d_{50}<1 \mathrm{~mm}$ (Vandenberghe 1975). The diagram gives an evaluation on the hydrodynamic forces working during the deposition of the sediments. The values of the first percentile ' $\mathrm{C}$ ' i.e. coarser one-percentile value in micron were plotted against the median ' $M$ ', obtained from cumulative curves as shown in Figure 6. Three basic mode of sediment transport were identified i.e. rolling, uniform suspension and graded suspension (Mycielska 2011).

The diagram (Figure 6) ables to identify whether the sediment was transported as bedload (either rolling or saltation) and suspension or a mixed of both modes. The are two zones describing the mode of transportation in the figure, where the area marked with black and dashed lines represent the sediment depositional behaviour according to Ludwikowska-Kedzia (2000) and Passega (1964), respectively. In the Passega (1964) zone, sediment falls within the sector $\mathrm{N}-\mathrm{O}$ is transported by rolling, where areas sediment within the boundaries O-P and P-Q correspond to being transported as rolling and suspension and suspension 


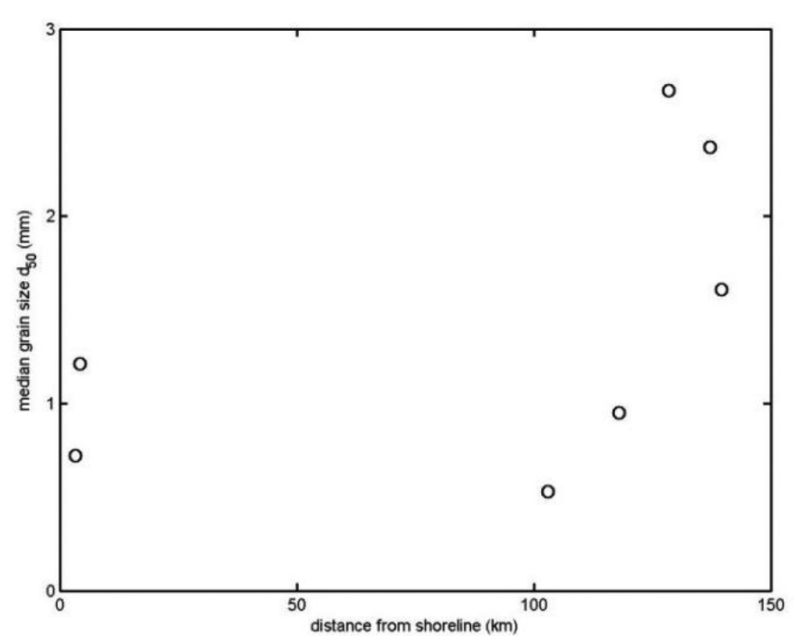

FIGURE 5 . The spatial variation of median grain size $d_{50}$ at different sampling points from various distance from shoreline

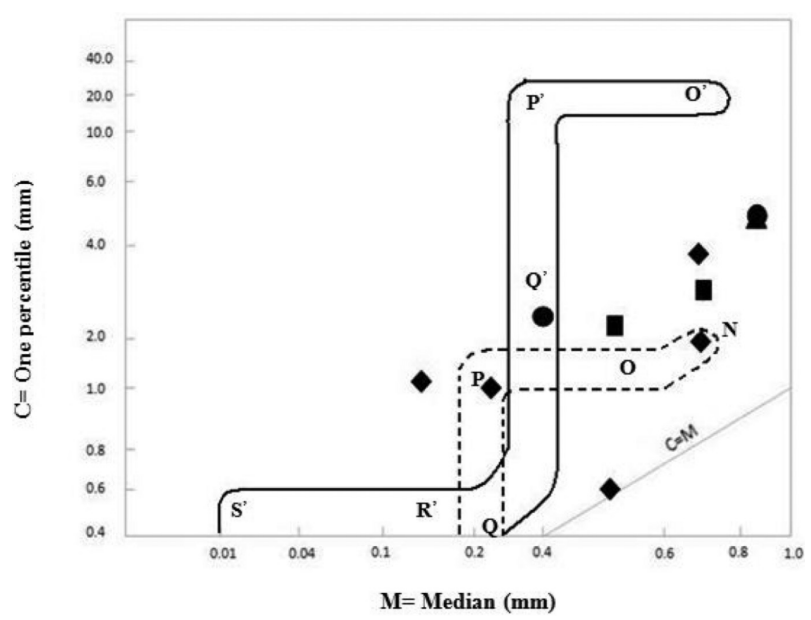

FIGURE 6. C-M diagram for samples obtained from Sungai Kelantan (•), Sungai Galas $(\bullet)$, Sungai Mei $(\bullet)$ and Sungai Sam $(\boldsymbol{\Delta})$. The plot was plotted according to Ludwikowska-Kedzia (2000) and Passega (1964), shown here as region with black and dashed lines, respectively

\& rolling, respectively. Note that the Passega zoning area is slightly different with the ones described by LudwikowskaKedzia (2000), where the mode of transportation is rolling between O'-P', saltation and rolling (P'-Q'), saltation (Q'-R') and suspension (R'-S').

Fluvial deposits in the rivers in Kelantan were identified to have varying mode of transport, ranging from rolling to suspension and rolling. We note however that most of the samples were not within the zones specified, where only three samples (i.e. Sungai Galas and Sungai Mei) fall under both regions. No samples were identified to be transported as suspended materials.

\section{CONCLUSION}

An accurate approximation of the parametric distributions of grain size are useful for the modelling of sediment transport, particularly to predict the erosion and depositional conditions. Detailed picture of the variation in the bed materials along the main rivers in Kelantan were obtained.

Rivers were categorised into sand and gravel dominated based on the percentage of sand and rivers available in the bed samples. The upstream rivers of Sungai Lata Tunggil and Sungai Sam were the gravel-dominated rivers where as Sungai Kelantan, Sungai Galas, Sungai Mei, Sungai Rek and Sungai Pengkalan Datu were dominated by sand. Minimal presence of clay and silt were found in all of the samples.

None of the collected samples falls under the category of uniformly/well distributed, where the samples were either very poorly sorted or poorly sorted. Wide range of grain size is evident for all samples except for Sungai Galas. Even so, the fluvial sediment found in the Kelantan rivers have high fractions of fine-grained sediment i.e. fine sand. The findings correspond with the CM pattern analysis where most of the sediment form is by either rolling or combination of both rolling and saltation.

\section{ACKNOWLEDGMENTS}

This research was financially supported by the Ministry of Education (ERGS/1/2013/TK03/UKM/02/7) and the Ministry of Science, Technology and Innovation (06-0102-SF-1077). We thank Mohd Faizan and Ahmad Amirul for their assistance during the field work.

\section{REFERENCES}

Ahmad, A.K., Mushrifah, I. \& Mohamad, S.O. 2009. Water quality and heavy metal concentrations in sediment of Sungai Kelantan, Kelantan, Malaysia: A baseline study. Sains Malaysiana 38(4): 435-442.

Ambak, M.A. \& Zakaria, M.Z. 2010. Freshwater fish diversity in Sungai Kelantan. Journal of Sustainability Science and Management 5(1): 13-20.

Blott, S.J. \& Pye, K. 2001. Gradistat: A grain size distribution and statistics package for the analysis of unconsolidated sediments. Earth Surface Processes and Landforms 26: 1237-1248.

Di Stefano, C. \& Ferro, V. 2002. Linking clay enrichment and sediment delivery processes. Biosystem Engineering 81(4): 465-477.

Folk, R.L. \& Ward, W.C. 1957. Brazos Sungai Bar: A study in the significance of grain size parameters. Journal of Sedimentary Petrology 27(1): 3-26.

Gomez, B., Rosser, B.J., Peacock, D.H. \& Hicks, D.M. 2001. Downstream fining in a rapidly aggrading gravel bed river. Water Resources Research 37(6): 1813-1823.

Hajek, E.A., Huzurbazar, S.V., Mohrig, D., Lynds, R.M. \& Heller, P.L. 2010. Statistical characterization of grain-size distributions in sandy fluvial system. Journal of Sedimentary Research 80: 184-192.

Ibbitt, R., Takara, K., Mohd Nor, M.D. \& Pawitan, H. 2002. Catalogue of Rivers for Southeast Asia and The Pacific. (Vol. 4). United Nations Educational Scientific Cultural Organizations (UNESCO).

Kiat, C.C., Ghani, A.A., Zakaria, N.A., Abu Hasan, Z. \& Abdullah, R. 2011. Sediment transport equation assessment 
for selected rivers in Malaysia. 3rd International Conference on Managing Rivers in the 21st Century. Penang, Malaysia.

Ludwikowska-Kędzia, M. 2000. Ewolucja środkowego odcinka doliny rzeki Belnianki w późnym glacjale i holocenie (Evolution of the Middle Segment of the Belnianka River Valley in the Late Glacial and Holocene). Warsaw: Dialog Press. p. 180.

McLaren, P. \& Bowles, D. 1985. The effects of sediment transport on grain-size distribution. Journal of Sedimentary Research 55(4): 457-470.

Miiliman, J.D. \& Ren, M. 1995. Climate Change: Impact on Coastal Habitation, Chapter 4: River Flux to the Sea: Impact of Human Intervention on River Systems and Adjacent Coastal Area. New York: CRC Press.

Mycielska-Dowgiallo, E. \& Ludwikowska-Kedzia, M. 2011. Alternative interpretations of grain-size data from Quarternary deposits. Geologos 17(4): 189-203.

Passega, R. 1964. Grain size representation by CM patterns as a geological tool. Journal of Sedimentary Petrology 34: 830-847.

Passega, R. \& Byramjee, R. 1969. Grain-size image of clastic deposits. Sedimentology 13: 233-252.

Rhoton, F.E., Emmerich, W.E., Nearing, M.A., McChesny, D.S \& Ritchie, J.C. 2011. Sediment source identification in a semiarid watershed at soil mapping unit scales. Catena 87: 172-181.

Thomas, M.F. 2003. Late Quaternary sediment fluxes from tropical watersheds. Sedimentary Geology 162: 63-81.
Sahu, B.K. 1964. Depositional mechanicsm from the size analysis of clastic sediments. Journal of Sediment Petology 34: 73-83.

Samsudin, A.R., Haryono, A., Hamzah, U. \& Rafek, A.G. 2007. Salinity mapping of coastal groundwater acquifers using hydrogeochemical and geophysical methods: A case study from north Kelantan, Malaysia. Environmental Geology 55: 1737-1743.

Sonaye, S.Y. \& Baxi, R.N. 2012. Particle size measurement and analysis of flour. International Journal of Engineering Research and Applications 2(3): 1839-1842.

Surian, N. 2002. Downstream variation in grain size along an Alpine river: Analysis of controls and process. Geomorphology 43: 137-149.

Vandenberghe, N. 1975. An evaluation of CM patterns for grain-size studies of fine grained sediments. Sedimentology 22: 615-622.

Jabatan Kejuruteraan Awam \& Struktur

Fakulti Kejuruteraan \& Alam Bina

Universiti Kebangsaan Malaysia

43600 UKM Bangi, Selangor Darul Ehsan

Malaysia

*Corresponding author; email: hanna@ukm.edu.my

Received: 5 February 2015

Accepted: 17 October 2016 